Nowoczesne Systemy Zarządzania Zeszyt 12 (2017), nr 1 (styczeń-marzec) ISSN 1896-9380, s. 91-103

Modern Management Systems Volume 12 (2017), No. 1 (January-March) ISSN 1896-9380, pp. 91-103

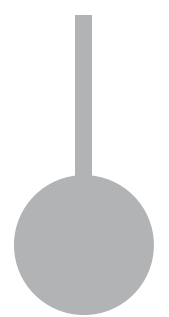

Instytut Organizacji i Zarządzania

Wydział Cybernetyki

Wojskowa Akademia Techniczna

w Warszawie

Institute of Organization and Management

Faculty of Cybernetics

Military University of Technology

\title{
Miejsce kapitału ludzkiego w organizacji
}

\section{Place of the human capital in the organization}

\author{
Janusz Wiśniewski \\ Wojskowa Akademia Techniczna \\ e-mail: zitaheim@poczta.onet.pl
}

\begin{abstract}
Abstrakt: $W$ prezentowanym opracowaniu opisano zasady prowadzenia polityki personalnej (kadrowej), za którą uznano całokształt form i metod pracy przełożonego z podwładnym, przy wykorzystaniu rozmaitych sił i środków. W takim ujęciu nieodzowne było zdefiniowanie pojęcia efektywnej pracy, którą można określić jako aktywność działalności ludzkiej zmierzającą do realizacji podstawowych zadań i celów zakładu pracy. Treść artykułu zawiera teoretyczne i praktyczne odniesienia do tematyki budowania lojalnej, ustabilizowanej załogi, przez to i efektywnej, przynoszącej zyski organizacji. Wskazane zostały elementy tworzące kapitał ludzki, ujmowany jako zbiorowa kompetencja firmy do wydobywania najlepszych rozwiązań za pomocą wiedzy pracowników. Podkreślono cechę zasobów ludzkich, którą jest ich odnawialność, związana z uczeniem się i doskonaleniem, co może być traktowane jako społeczna rezerwa organizacji. Autorzy zaznaczają jednocześnie różnicę jakościową pojęć - zasoby ludzkie i kapitał ludzki, odnosząc się do różnorodności pojawiających się typów zarządzania, np. wiedzą, kompetencjami, zasobami ludzkimi, talentami itp. W tekście wskazano najbardziej popularne modele procesu zarządzania zasobami ludzkimi oraz rekrutacji.
\end{abstract}

Słowa kluczowe: zasoby ludzkie, kapitał, organizacja, zarządzanie, rekrutacja

Abstract: In the presented study principles of conducting the personnel policy were described (personnel) which the entirety of forms and methods of the work of the superior was regarded with the subordinate, as at using various forces and funds. In such a presentation defining comprehending the effective work which it is possible to describe the activity of human activity heading the realization of basic tasks and targets of the workplace was essential. Contents of the article contain theoretical and practical references to the subject matter of building the loyal, stabilized crew up, because of that and of the organization effective, bringing in a profit. Elements creating the human capital, included as collective competence of the company in getting better solutions with the knowledge of employees were recommended. A feature of human resources which their renewable-ness, associated with the learning and improving is, was being highlighted what can be treated as the social reserves of the organization. 
Authors are emphasizing the quality difference of notions simultaneously human resources and the human capital, referring to the diversity of appearing types of managing knowledge, competence, human resources, talents e.g. and the like.

Keywords: human resources, capital, organization, work, management

\section{Wstęp}

Czynnik ludzki tworzą konkretne jednostki i grupy ludzkie wypełniające struktury organizacyjne oraz realizujące w organizacjach zarówno obowiązki i zadania wynikające z pełnionych przez siebie ról, jak i swoje własne cele i dążenia. Dla opisania czynnika ludzkiego najczęściej są używane określenia, które służą podkreśleniu znaczenia ludzi dla realizacji celów organizacyjnych i uznania ich za podstawowy składnik ekonomicznej wartości organizacji. W tym znaczeniu mówi się o zasobach ludzkich (Koźmiński, Jemielniak, 2011, s. 94).

Kolejnym pojęciem, które łączy się z zagadnieniami dotyczącymi czynnika ludzkiego jest definicja polityki personalnej. Polityka personalna (polityka kadrowa) to całokształt form i metod pracy przełożonego z podwładnym, zespół środków oddziałujących na pracownika, które skłaniają go do efektywnej pracy, czyli do aktywnej działalności zmierzającej do realizacji podstawowych zadań i celów zakładu pracy (Nowicka, 2014, s. 123-136). Można zatem uznać, iż przez termin polityki kadrowej rozumie się system skoordynowanych, długofalowych działań nastawionych na ukształtowanie załogi sprawnie realizującej cele organizacji i jej uczestników: właścicieli, kierownictwa, pracowników i klientów. Ustalenie zasad i kierunków polityki kadrowej jest niezbędnym warunkiem zapewnienia ciągłości stosowanych w zakładzie pracy metod zarządzania, sprzyjających zbliżeniu interesów pracownika i zatrudniającej go organizacji, a tym samym umożliwiających zbudowanie lojalnej, ustabilizowanej załogi (Ciekanowski, 2013, s. 87).

\section{Znaczenie kapitału ludzkiego}

Kapitał ludzki jest nieodłącznie związany z człowiekiem, jego umiejętnościami, wiedzą, doświadczeniem i działaniem w organizacji. Jest on zbiorową kompetencją firmy do wydobywania najlepszych rozwiązań za pomocą wiedzy pracowników. Nie jest on zatem własnością organizacji, ponieważ wraz z odejściem pracownika traci ona pewne umiejętności, doświadczenie związane z opanowaniem określonych mechanizmów działania, wiedzę czy nieformalne powiązania. Kapitał ludzki tworzą cechy osobowe wnoszone do pracy, zdolności do uczenia się, motywacja dzielenia się informacjami i wiedzą.

S.R. Domański kapitał ludzki przedstawia jako zasób wiedzy, umiejętności, zdrowia i energii witalnej, zawarty w każdym człowieku i społeczeństwie jako całości, 
określający zdolności do pracy, adaptacji i zmian w otoczeniu oraz możliwości kreacji nowych rozwiązań (Domański, 1993, s. 96). Na kapitał ludzki składają się wartości przedsiębiorstwa, jego kultura organizacyjna i filozofia. Cechy kapitału ludzkiego przyjmują (Listwan, 2005, s. 73):

- jakościowy charakter zagadnienia;

- obraz trudny do ewidencji i pomiaru;

- postać ukształtowaną procesowo, siłami własnymi jednostki i organizacji;

- charakter, który nie może być przedmiotem obrotu towarowego;

- osobliwy charakter, który nie może zmieniać właściciela;

- rys unikalny, trudny do naśladowania przez konkurencję.

W literaturze przedmiotu przedstawiane są różne propozycje strukturyzacji kapitału ludzkiego z perspektywy firmy. Według J. Roosa, G. Roosa i N.C. Dragonettiego kapitał ludzki tworzą trzy elementy: kompetencje, postawy i sprawność umysłowa, co przedstawiono na schemacie nr 1.

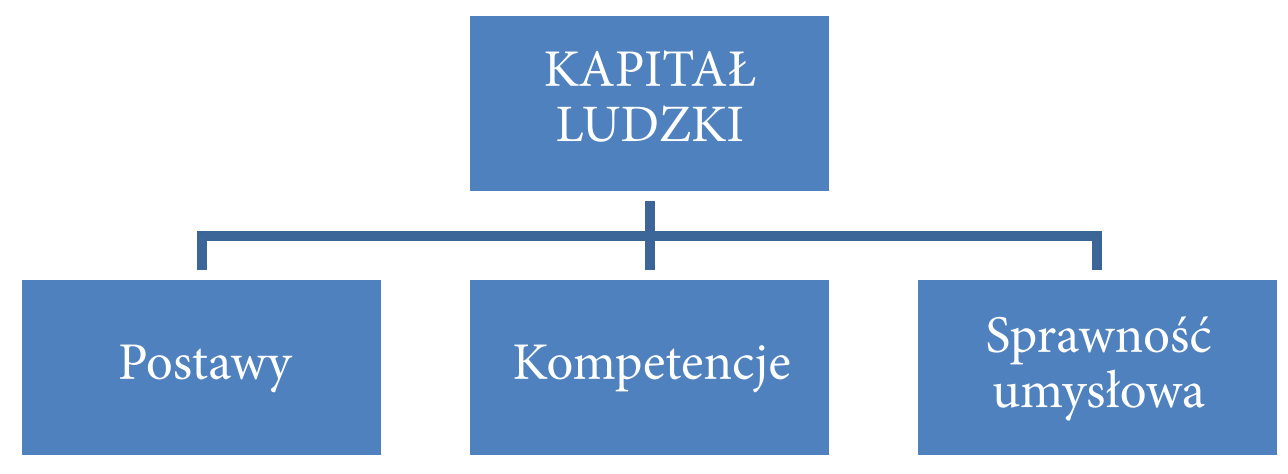

Schemat 1. Struktura kapitału ludzkiego wg J. Roosa, G. Roosa i N.C. Dragonettiego

Źródło: J. Roos, G. Roos, N.C. Dragonetti, Intelelectual Capital-Navigating in the New Business Landscape, Macmillan Press, 1997, s. 98

Postawy w przedstawionej strukturze kształtowane są przez motywację, zachowania i wyznawane poglądy. Kompetencje przedstawiane są jako połączenie wiedzy, umiejętności i możliwości pracownika, które to elementy tworzą nową wartość. Natomiast sprawność umysłową autorzy definiują, jako umiejętność analizowania i wnioskowania oraz skłonność do innowacji (Roos, Roos, Dragonetti, 1997, s. 116).

Kapitał ludzki jest najważniejszym zasobem w przedsiębiorstwie, o czym może świadczyć fakt, że współczesne organizacje inwestują więcej w ludzi niż w technologię. Zgromadzony w ludziach kapitał pełni rolę nadrzędną w organizacji i pośrednio wpływa na jej efektywność.

Zasoby ludzkie są niezwykle ważne w procesie gospodarowania nimi. Ich cechy takie jak: możliwość uczenia się, doskonalenie swojego potencjału czy kreatywność, umożliwiają dostrzeganie szans i zagrożeń wewnątrz i na zewnątrz firmy oraz wykorzystywanie tych pierwszych, a ograniczanie drugich (Ciekanowski, 2014a, s. 140-142). 
Zasoby ludzkie stanowią społeczną rezerwę organizacji - zapas ludzkiej energii oraz wiedzy, umiejętności i nawyków, które można skierować ku realizacji misji i celów organizacji, ale które mogą także samoistnie oddziaływać w najróżniejszy, często niekontrolowany sposób na organizację i jej otoczenie (Ciekanowski, 2012a, s. 148).

Zasoby ludzkie zalicza się do zasobów odnawialnych, w przeciwieństwie do większości zasobów naturalnych i rzeczowych. Ludzie mają zdolność do uczenia się i ciągłego doskonalenia, natomiast cechą pozostałych zasobów jest ich stopniowa deprecjacja i zużywanie się. Zasoby ludzkie obejmują aktywność, umiejętności i wiedzę zatrudnionych ludzi, określa się je, jako zasób pracy lub siłę roboczą (Ciekanowski, 2012a, s. 186).

\section{Czynnik ludzki w organizacji: zasób, czy kapitał?}

Zupełnie inne znaczenie ma postrzeganie ludzi jako zasób, a inne jako kapitał. Zasoby są nagromadzonym dobrem, które może być wykorzystywane w procesie produkcji, efekty zastosowania zależą od jakości i ilości zasobu. Z racji tego, iż podejście do ludzi, jako zasobu, jest podejściem całościowym, przedsiębiorstwo inwestuje w swoje kadry (poprzez liczne szkolenia) licząc, iż lepsza jakość, czyli wartość kadr, przełoży się na wyniki.

Kapitał natomiast jest to kategoria finansowa i dynamiczna. O istocie kapitału decyduje ruch, obrót, wykorzystywanie. W stanie spoczynku kapitał staje się zasobem. W konsekwencji takiego podejścia pracownicy oceniani są przez pryzmat osiąganych wyników faktycznych, co wymusza rozwój narzędzi pomiaru tych efektów. Miarą wartości pracownika jest talent czy potencjał (Jamka, 2011, s. 91).

Przejście w postrzeganiu czynnika ludzkiego z zasobu do kapitału jest wynikiem zmian dokonujących się w społeczno-gospodarczym otoczeniu przedsiębiorstw. Sformułowanie teorii zasobowej firmy, determinującej przewagę konkurencyjną przedsiębiorstwa, spowodowało postrzeganie ludzi jako zasobu. Dynamiczną progresję zarządzania strategicznego pobudził rozwój podejścia strategicznego w zarządzaniu zasobami ludzkimi. Postrzeganie ludzi jako kapitału jest przede wszystkim konsekwencją przyjęcia maksymalizacji wartości rynkowej przedsiębiorstwa jako najważniejszego celu jego działalności. Koncentracja na budowaniu wartości przedsiębiorstwa skierowała zainteresowanie nauki i praktyki zarządzania na źródła kreowania wartości przedsiębiorstwa. Zwrócono się przede wszystkim $\mathrm{w}$ stronę tego, co funkcjonuje w znacznej mierze poza bilansem finansowym, czyli w kierunku kapitału intelektualnego - z kapitałem ludzkim jako główną składową. Ponadto efektem postępującego zjawiska umiędzynarodowienia życia gospodarczego staje się dematerializacja pracy. Toteż wykorzystując czynnik ludzki, przedsiębiorstwa nie muszą już posiadać własnych zasobów w zbudowanych dla nich lokalizacjach. 
W wyniku tego praca staje się płynna, a świadczący ją pracownik staje się kapitałem (Jamka, 2011, s. 91). W konsekwencji, istota zarządzania kapitałem ludzkim jest różna od istoty zarządzania zasobami ludzkimi.

Modelowy typ zarządzania ludźmi w przedsiębiorstwie współgra ze strategią ogólną, celami i wyznacznikami ich realizacji. Wymaga także spójności z wykorzystywanymi metodami i technikami zarządzania ludźmi. Dlatego dokonujące się zmiany w postrzeganiu roli ludzi w przedsiębiorstwie znajdują odbicie w popularnych praktykach funkcji personalnej. Często mamy do czynienia z pojawieniem się zjawiska mód w zarządzaniu, co powoduje powstanie nowych metod zarządzania kadrami. Przykładem mogą być zarządzanie kompetencjami, zarządzanie wiedzą, zarządzanie talentami czy zarządzanie różnorodnością.

Warto jednak do podanych koncepcji podejść z pewną dozą krytycyzmu. Przykładowo, zarządzanie kompetencjami jest spójne z zarządzaniem zasobami ludzkimi i niespójne z zarządzaniem kapitałem ludzkim. Zarządzanie oparte na kompetencjach opisuje bowiem te same cechy, które zostały zidentyfikowane jako podstawowe wyznaczniki zarządzania zasobami ludzkimi. Celem pomiaru kapitału ludzkiego jest wyznaczanie strategii przedsiębiorstwa przez określenie jego mocnych stron. Kompetencje tworzone są w odpowiedzi na oczekiwania kwalifikacyjne wobec pracowników. Zarządzanie kapitałem ludzkim koncentruje się na silnych stronach potencjału kadr, natomiast zarządzanie kompetencjami - na ich stronach słabych: ich wychwytywaniu i niwelowaniu.

Obserwacja pojawiających się lub popularnych praktyk personalnych w przedsiębiorstwach wskazuje na zachodzącą zmianę w zarządzaniu kadrami: od zasobowego do kapitałowego (Jamka, 2011, s. 91).

\section{Zarządzanie zasobami ludzkimi oraz jego modele}

Nim zostaną opisane wybrane modele zarządzania zasobami ludzkimi niezbędne wydaje się wyjaśnienie, czym jest zarządzanie zasobami ludzkimi. Otóż zarządzanie zasobami ludzkimi (ZZL) jest to strategiczne i spójne podejście do zarządzania najcenniejszymi aktywami organizacji, to znaczy zatrudnionymi w niej ludźmi, którzy indywidualnie i zbiorowo przyczyniają się do osiągnięcia celów tej organizacji (Armstrong, 2007, s. 63). Zarządzanie zasobami ludzkimi jest określoną koncepcją zarządzania w obszarze funkcji personalnej przedsiębiorstw, w której zasoby ludzkie postrzega się, jako składnik aktywów firmy i źródło konkurencyjności. Postuluje się $\mathrm{w}$ tym ujęciu strategiczną integrację spraw personalnych ze sprawami biznesowymi, aktywną rolę kierownictwa liniowego w rozwiązywaniu kwestii personalnych oraz wskazuje się na potrzebę kształtowania kultury organizacyjnej, integracji procesów personalnych oraz budowania zaangażowania pracowników, jako narzędzi osiągania celów (Pocztowski, 2007, s. 121). 
Jednymi z najbardziej znanych modeli zarządzania zasobami ludzkimi są:

- model Michigan;

- model harwardzki;

- model Schulera.

Model Michigan zakłada, iż organizacja pozostaje pod wpływem sił ekonomicznych, politycznych i kulturowych. Misja i strategia przedsiębiorstwa wyznaczają jego strukturę organizacyjną i stosowane rozwiązania w zakresie zarządzania zasobami ludzkimi. W tym przypadku struktura podąża za strategią (Fombrun, Tichy, Devanna, 1984, s. 37). W modelu Michigan przyjęto minimum dwukierunkową zależność pomiędzy zarządzaniem zasobami ludzkimi a strukturą organizacyjną. Proces zarządzania zasobami ludzkimi ujęto $\mathrm{w}$ formie cyklu, który składa się z czterech wzajemnie powiązanych subfunkcji: selekcji, oceniania, wynagradzania i rozwoju pracowników. Ukształtowanie poszczególnych elementów cyklu umożliwia skuteczne oddziaływanie na zachowanie pracowników. Zadaniem kierownictwa przedsiębiorstwa jest takie powiązanie systemu zarządzania zasobami ludzkimi ze strategią organizacji, które umożliwia osiąganie celów strategicznych organizacji (Luty, Wiśniewski, 2016, s. 107-116), co starano się ująć w schemacie nr 2.

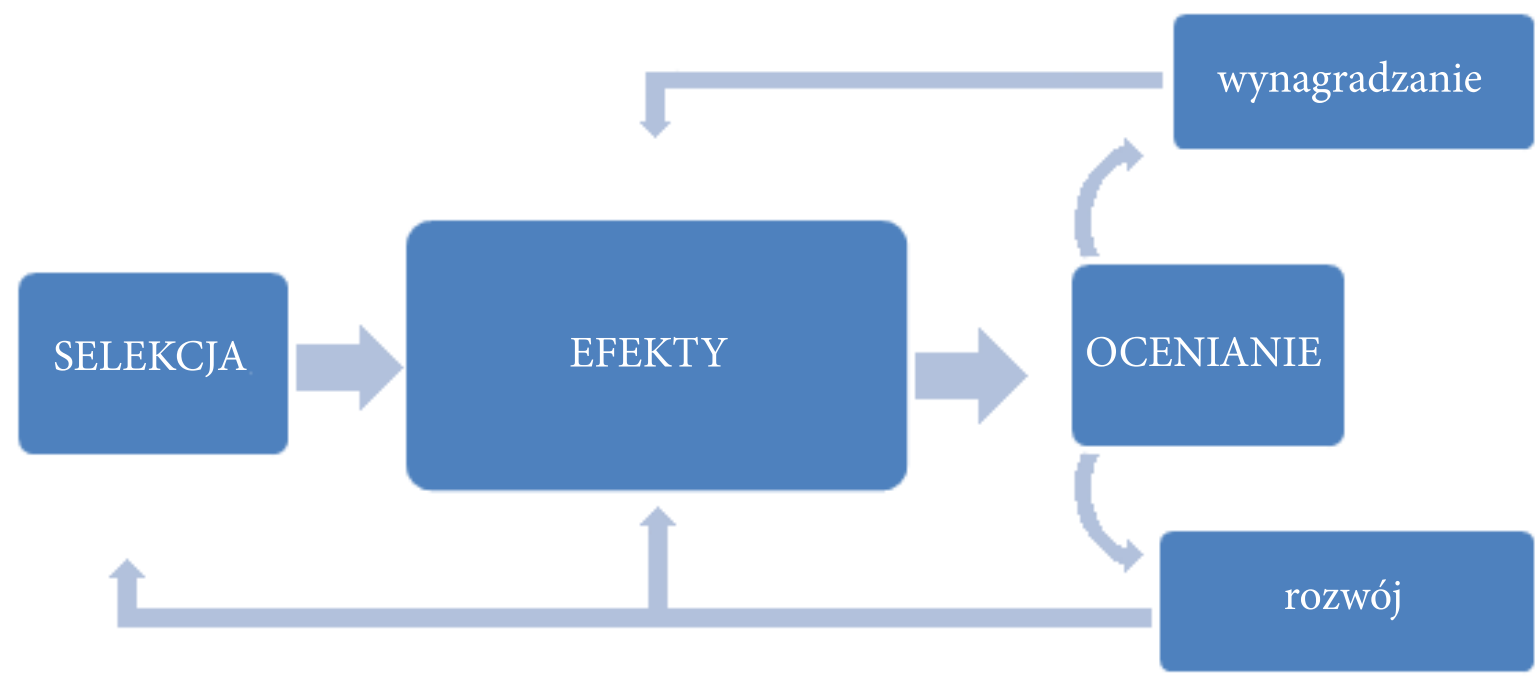

Schemat 2. Cykl zarządzania zasobami ludzkimi w modelu Michigan Źródło: por. A. Pocztowski, 2007, s. 86

Kolejnym wartym przedstawienia modelem zarządzania zasobami ludzkimi jest tzw. model harwardzki. Uwzględnia on cztery płaszczyzny zarządzania zasobami ludzkimi: partycypację pracowników, przepływ pracowników, system nagród i system pracy. Na obszary te mają wpływ interesariusze (akcjonariusze, kierownictwo, pozostali pracownicy, samorząd i rząd), a także czynniki sytuacyjne, do których - obok rodzajów zasobów pracy, filozofii zarządzania, rynku pracy, techniki i technologii, prawa oraz społecznych wartości - zaliczono również strategię przedsiębiorstwa. 
Podjęte działania prowadzą do pewnych skutków dotyczących zasobów ludzkich, np. zaangażowania pracowników, określonej produktywności - które kształtują długookresowe skutki w postaci indywidualnego dobrobytu oraz efektywność organizacji. Natomiast długookresowe skutki wpływają na interesariuszy, strategię przedsiębiorstwa oraz pozostałe czynniki sytuacyjne. Model harwardzki stanowi mapę zależności przyczynowo-skutkowych pomiędzy determinantami i konsekwencjami zarządzania zasobami ludzkimi (balewski.pl, 2016).

Model Schulera ukazuje generalne znaczenie otoczenia wewnętrznego oraz zewnętrznego organizacji w kształtowaniu strategii organizacji, która stanowi bodziec do tworzenia strategii zarządzania zasobami ludzkimi. Działania w zakresie strategicznego zarządzania zasobami ludzkimi obejmują według tej koncepcji określenie (Ciekanowski, 2012a, s. 164):

- filozofii zasobów ludzkich, czyli sposobów traktowania i wartościowania pracowników;

- polityki zasobów ludzkich, tzn. definiowania poszczególnych składników wartościujących personel;

- programu zarządzania zasobami ludzkimi, czyli wyznaczenia składników strategii zasobów ludzkich;

- praktyki zarządzania zasobami ludzkimi, która obejmuje zakres realizowanych ról na poszczególnych stanowiskach;

- procesów zarządzania zasobami ludzkimi zawierających sposoby realizacji powierzonych ról.

\section{Podstawowe funkcje zarządzania zasobami ludzkimi}

W dużych przedsiębiorstwach warto podstawowe funkcje zarządzania zasobami ludzkimi odnieść do czterech funkcji zarządzania w ogóle. Zatem funkcjami kluczowymi w obszarze zatrudnienia mogą być kategorie:

- planowanie zatrudnienia;

- organizowanie kadr (zespołów pracowniczych);

- motywowanie pracowników;

- kontrolowanie pracowników.

Planowanie zatrudnienia ma na celu ustalenie przyszłych potrzeb kadrowych przedsiębiorstwa i przygotowanie działań umożliwiających ich zaspokojenie. Pojmowane szeroko obejmuje określenie: rodzaju i liczby przyszłych pracowników, sposobów ich rekrutacji, metod doboru, potrzeb szkoleniowych i kierunku rozwoju, sposobów doskonalenia oraz aktywizowania. Planowanie powinno obejmować także przygotowanie koniecznych i alternatywnych zwolnień, z rozbiciem na poszczególne jednostki organizacyjne i okresy. Planowanie zatrudnienia jest procesem ciągłym i nie powinno się ograniczać do wybranych momentów w rozwoju organizacji. 
Najbardziej pracochłonnymi i czasochłonnymi etapami planowania jest wdrażanie planów i programów działania oraz ich kontrola i ocena. Ogólnie mówiąc, planowanie zmierza do ulokowania odpowiednich ludzi we właściwym miejscu i czasie - zgodnie z celami przedsiębiorstwa.

Organizowanie kadr (zespołów pracowniczych) oznacza właściwe i pełne wykorzystanie potencjału pracowników oraz takie podejście do zatrudnienia, by przedsiębiorstwo mogło efektywnie działać. Wymaga to odpowiedniego zaplanowania procesów produkcyjnych, usługowych oraz obsługi w przedsiębiorstwie. Konieczne jest zatem określenie funkcji poszczególnych struktur organizacyjnych i celów dla zespołów, hierarchizacja zadań, podział i formułowanie ich dla poszczególnych pracowników, a także dobór pracowników do poszczególnych zadań ze względu na ich kompetencje. Dlatego z funkcją organizowania kadr wiąże się rekrutacja i selekcja pracowników oraz adaptacja, integracja i doskonalenie zatrudnionych. Są to elementy pracy kadrowej mające charakter oddziaływań organizujących, które są niezbędne nie tylko do zapewnienia odpowiedniego poziomu pracy, lecz także do powstania i podtrzymania więzi między organizacją a zatrudnionymi. Rekrutacja (wewnętrzna lub zewnętrzna), selekcja kandydatów oraz wprowadzenie do pracy to pierwszy, wstępny, ale bardzo ważny etap organizowania personelu. Adaptacja jest elementem przygotowania pracowników do pracy, integracja zaś to zazwyczaj dłuższy proces, mający na celu połączenie interesów i dążeń poszczególnych osób z celami i dążeniami organizacji. Problem szeroko rozumianego doskonalenia można traktować, jako zadanie stałe, ściśle związane ze zmiennością otoczenia oraz indywidualnymi aspiracjami. Każde przedsiębiorstwo potrzebuje pracowników o kwalifikacjach zgodnych z bieżącymi potrzebami. Zestawienie ustalonych przez organizację wymagań $\mathrm{z}$ kwalifikacjami osób zatrudnionych pozwala określić najważniejsze z punktu widzenia interesów firmy kwalifikacje oraz kierunki szkoleń uzupełniających wiedzę, a także przygotować program doskonalenia rozwijającego posiadane lub potencjalne umiejętności.

Motywowanie jest jedną z najważniejszych funkcji zarządzania zasobami ludzkimi (Ciekanowski, 2011, s. 100-101). Obejmuje ono tworzenie takich warunków i stosowanie takich bodźców, aby pracownik zachowywał się zgodnie z potrzebami organizacji (Ciekanowski, Nowicka, 2014, s. 130-131). Motywowanie bezpośrednio wiąże się z systemami wynagrodzeń. Satysfakcja pracowników z oferowanego im wynagrodzenia zależy między innymi od:

- poziomu wynagrodzenia postrzeganego, jako odpowiednie zabezpieczenie materialne, zapewniające dobrą jakość życia;

- dopasowania sposobu wynagradzania do preferencji pracowników;

- wpływu pracownika na wielkość wynagrodzenia poprzez jakościowe i ilościowe właściwości wykonywanej przez niego pracy;

- relacji między wysokością otrzymanego wynagrodzenia a wysokością wynagrodzenia, jakie według pracownika powinien on otrzymać. 
Kontrola jest powiązana $\mathrm{z}$ funkcją organizowania, planowania i motywowania, a rezultaty kontroli mają wpływ na dalszą realizację tych funkcji. Celem kontroli nie jest oczywiście wyszukiwanie winnych i ich karanie, lecz szczegółowe analizowanie przyczyn niepowodzeń oraz pomoc w dalszej realizacji zadań. Dlatego w procesie kontrolnym niezwykle ważne jest ustalenie celów, standardów i zadań, wraz z terminami ich realizacji, oraz precyzyjne określenie zakresu odpowiedzialności pracowników. Dobrze skonstruowane mechanizmy kontrolowania pracowników są skuteczne także w odniesieniu do kontroli menedżerów - ich umiejętności kierowniczych, jakości ich pracy oraz efektywności systemu zarządzania (Ciekanowski, 2014b, s. 234).

\section{Model sita i model kapitału ludzkiego}

Przyjmując nowych pracowników do przedsiębiorstwa, można zastosować jedno $\mathrm{z}$ dwóch odmiennych podejść. Model sita i model kapitału ludzkiego są przeciwnymi sposobami selekcji zatrudnianych ludzi. Na oba modele składa się seria realizowanych zadań: rekrutacja, selekcja członków organizacji, nagradzanie, karanie i rozwój.

Model sita oznacza podejście, zgodnie z którym organizacja jest przede wszystkim selekcjonerem zasobów ludzkich. Dobiera się najlepszych spośród możliwych kandydatów na pracowników i stopniowo pozbywa się tych gorszych. Cały proces zaczyna się od ustalenia wymaganych kwalifikacji u pretendujących do pracy, następnie po zebraniu zgłoszeń przeprowadza się kolejne selekcje, odrzucając osoby niespełniające tych wymogów. Dzieje się to tak długo, aż zostaną znalezione osoby o odpowiednich kwalifikacjach, które zostaną zatrudnione.

Model kapitału ludzkiego cechuje podejście do zarządzania potencjałem społecznym opierające się na założeniu, że człowiek uczy się i zmienia przez całe życie (Ciekanowski, 2012b, s. 24-26). Organizacja stawia na zatrudnienie długookresowe i traktuje personel jako zasób, w który można i należy inwestować. Do pracy przyjmowani są ludzie z odpowiednim nastawieniem, nawet jeśli brakuje im kwalifikacji. Braki te pracownik uzupełnia w trakcie szkoleń oraz samodzielną nauką (Koźmiński, 2002, s. 58). W tabeli nr 1 znajdują się zalety oraz wady wymienionych dwóch modeli. 
Tabela 1. Zalety oraz wady modeli sita i kapitału ludzkiego

\begin{tabular}{|c|c|c|}
\hline & ZALETY & WADY \\
\hline $\begin{array}{c}\text { MODEL } \\
\text { SITA }\end{array}$ & 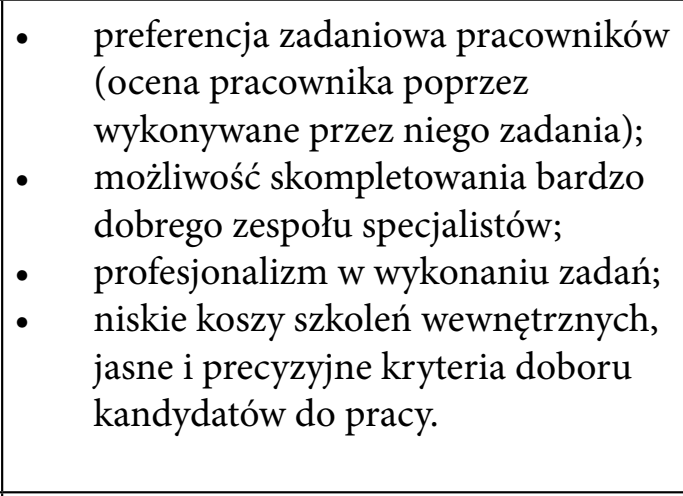 & $\begin{array}{l}\text { - } \quad \text { duża fluktuacja pracowników; } \\
\text { - } \quad \text { zwiększona konkurencja } \\
\text { i rywalizacja wśród pracowników; } \\
\text { brak poczucia bezpieczeństwa } \\
\text { i stabilności zawodowej; } \\
\text { - } \quad \text { wysokie koszty osobowe } \\
\text { (wysokie płace dla najlepszych); } \\
\text { - docenianie tylko najlepszych, } \\
\text { skutecznych, efektywnych } \\
\text { (z pominięciem zaangażowania). }\end{array}$ \\
\hline $\begin{array}{c}\text { MODEL } \\
\text { KAPITAŁU } \\
\text { LUDZKIEGO }\end{array}$ & $\begin{array}{l}\text { - } \quad \text { stabilizacja pracowników; } \\
\text { zaangażowanie pracowników } \\
\text { w funkcjonowanie organizacji, } \\
\text { poczucie misji; } \\
\text { kreatywność pracowników, niskie } \\
\text { koszty osobowe. }\end{array}$ & $\begin{array}{l}\text { - } \quad \text { wysokie koszty szkoleń; } \\
\text { trudne do pomiaru kryteria } \\
\text { kwalifikacyjne; } \\
\text { zanikanie poziomu rywalizacji } \\
\text { między pracownikami. }\end{array}$ \\
\hline
\end{tabular}

Źródło: A. Koźmiński, Zarządzanie: teoria i praktyka, PWN, Warszawa 2002, s. 58

Porównując przedstawione modele, nie sposób jednoznacznie wskazać, który jest lepszy. Ocena zależy od specyficznych warunków panujących w firmie oraz w jej otoczeniu, na przykład od sytuacji na rynku pracy. Często stosuje się pomieszanie obydwu metod, gdzie zaczyna się od ostrej selekcji, a następnie szkoli się wybranych pracowników oraz rozwija się ich kompetencje i umiejętności (Koźmiński, 2002, s. 58).

\section{Ogólne zasady polityki personalnej}

Zgłębiając zagadnienie polityki personalnej, można wyróżnić kilka zasad stanowiących jej trzon. Proponuje się zatem podział, w skład którego wchodzi (Król, Ludwiczyński, 2006, s. 73):

- Zasada apartyjności - należy unikać podejścia partyjnego w polityce personalnej. Nie należy kierować się interesem swojej partii oraz „kolesiów”. Niestosowanie tej zasady może powodować konflikty wśród pracowników, wywodzących się z przedstawicieli różnych opcji politycznych. Skutkuje to spadkiem efektywności i działania.

- Zasada obiektywności - polityka personalna powinna się opierać na zasadach rzetelności i bezstronności. Działania powinny być wolne od przesądów i uprzedzeń.

- Zasada praworządności - w procesie realizacji polityki personalnej nie powinny mieć miejsca działania niezgodne z prawem lub na jego pograniczu. 
Działania personalne są usankcjonowane wieloma aktami normatywnymi, przepisami prawnymi i układami pracy.

- Zasada kompleksowości - w polityce personalnej nie należy się ograniczać do działań fragmentarycznych. Narzędzia kierowania ludźmi (m.in. ocena, rezerwa kadrowa) nie powinny się przekształcać w autonomiczne przedsięwzięcia.

- Zasada racjonalności - należy unikać działań pozornych i formalnych (przykładem może być ogłaszanie konkursu na dane stanowisko, gdy z góry wiemy, kto otrzyma nominację). Aby ta zasada została zrealizowana, należy dokonywać analiz i prowadzić badania nad skutecznością działania poszczególnych ogniw, odpowiadających za realizację polityki personalnej.

- Zasada planowości - działania podejmowane w polityce personalnej nie powinny być przypadkowe. Założenia polityki personalnej powinny się ściśle wiązać $\mathrm{z}$ ogólną strategią organizacji. Istnieje potrzeba, by planować i programować działania personalne $z$ dużym wyprzedzeniem.

- Zasada humanizmu - oznacza, że pracownik nie może być traktowany przedmiotowo. Ludzie są najcenniejszym $z$ kapitałów w organizacji. Wysiłek pracownika może przyczynić się do realizacji celów założonych przez organizację. Trzeba zapewnić pracownikowi warunki do rozwijania talentu i aspiracji.

- Zasada jednolitości - przyjęte w polityce personalnej zasady powinny być stosowane we wszystkich ogniwach organizacji. Trzeba jednakowo postępować wobec innych, nie można stosować wyjątków.

- Zasada jawności - tworzenie systemów zarządzania ludźmi nie może się odbywać w atmosferze tajemniczości i utajnienia stosowanych zasad. Kryteria i tryb postępowania powinny być ogólnie znane. Należy prowadzić otwartą politykę personalną. Tylko niektóre zdarzenia personalne powinny być poufne.

- Zasada jasności i konkretności - zasady powinny być formułowane w sposób zrozumiały, nie powinny budzić wątpliwości i nie powinny być różnorako interpretowane. Należy stosować sformułowania precyzyjne.

- Zasada trwałości - założenia polityki personalnej powinny być stosowane przez dłuższy okres i nie powinny podlegać ciągłym zmianom. Dobre i sprawdzone rozwiązania stosowane w polityce personalnej powinny być kontynuowane bez zmian.

- Zasada ciągłości doskonalenia - ta zasada powinna być ściśle związana z zasadą trwałości i wymaga poszukiwania złotego środka. Nie należy prowadzić do utrzymania przestarzałych i nieżyciowych rozwiązań w polityce personalnej. Doskonalenie polityki personalnej prowadzi do doskonalenia się organizacji. Jest to rozumiane jako dokonanie zmian strukturalnych, technologicznych, skoncentrowanie się głównie na czynniku ludzkim oraz istocie i jakości stosunków pracy. 


\section{Podsumowanie}

Rekapitulując, można stwierdzić, iż jedną z głównych sił wytwórczych w przedsiębiorstwie jest czynnik ludzki. Jest on ograniczony i zarazem bardzo kosztowny, dlatego gospodarowanie tym czynnikiem jest centralnym problemem polityki personalnej.

Ludzie ze swoimi uzdolnieniami i ogromnym potencjałem możliwości stanowią bogactwo narodu, a od polityki personalnej zależy, w jakim stopniu będzie ona wykorzystana dla tworzenia nowych wartości. Przedsiębiorstwo, jako instytucja ekonomiczna, powinno starać się jak najlepiej wykorzystywać potencjał swoich pracowników. Istotą i zasadą życia przedsiębiorstwa jest realizacja celów ekonomicznych, co wiąże się z osiąganiem zysku. Cele ekonomiczne są realizowane przez ludzi, a jednocześnie dla ludzi, dlatego też właściciele powinni dbać o spełnianie oczekiwań i potrzeb pracowników. Ludzie, jako zasób przedsiębiorstwa, w przeciwieństwie do pozostałych zasobów znajdujących się w firmie posiadają osobowość, prawa obywatelskie oraz decydują o tym, czy w ogóle pracują, jak długo pracują oraz jak dobrze będą sprawować swoje obowiązki.

\section{BIBLIOGRAFIA}

[1] Armstrong M., 2007, Zarządzanie zasobami ludzkimi, Oficyna a Wolters Kluwer business, Kraków.

[2] Ciekanowski Z., 2011, Motywowanie jako instrument zarzadzania zasobami pracy, [w:] Zeszyty Naukowe Akademii Podlaskiej, Nr 89 Seria: Administracja i Zarządzanie (16)2011, Siedlce.

[3] Ciekanowski Z., 2012a, Czynnik ludzki wobec współczesnych wyzwań organizacji, (skrypt dla studentów kierunków zarządzania i ekonomii), AON, Warszawa.

[4] Ciekanowski Z., 2012b, Pozyskiwanie zasobów ludzkich i ich rozwój w nowoczesnej organizacji, wyd. W-W-W Wiesław Krzeszowski, Warszawa 2012.

[5] Ciekanowski Z., 2013, Jakość w zarządzaniu zasobami ludzkimi, PWST-E, Jarosław.

[6] Ciekanowski Z., 2014a, Zasoby ludzkie najważniejszym czynnikiem w organizacji, [w:] Innowacyjność w procesach zarzadzania i dowodzenia organizacjami publicznymi, Warszawa.

[7] Ciekanowski Z., 2014b, Determinanty bezpieczeństwa personalnego w zarządzaniu zasobami ludzkimi w nowoczesnej organizacji, Wydawnictwo PWST-E, Jarosław.

[8] Ciekanowski Z., Nowicka J., 2014, Miejsce i rola kultury organizacyjnej w motywowaniu pracowników, [w:] Zeszyty Naukowe Uniwersytetu Przyrodniczo-Naukowego w Siedlcach, nr 102, Seria Administracja i Zarządzanie (29) 2014, Siedlce.

[9] Domański S.R., 1993, Kapitał ludzki i wzrost gospodarczy, Spis, Warszawa.

[10] Fombrun C.J., Tichy N.M., Devanna M.A., 1984, Strategic Human Recourse Management, John Willey \& Sons Inc., New York.

[11] Golau W., 2007, Zarzadzanie zasobami ludzkimi, wyd. CeDeWu, Warszawa.

[12] JАмка B., 2011, Czynnik ludzki we wspótczesnym przedsiębiorstwie: zasób czy kapitał?, Wolters Kluwer, Warszawa. 
[13] KoźmiŃski A., 2002, Zarządzanie: teoria i praktyka, PWN, Warszawa.

[14] Koźmiński K. A., Jemielniak D., 2011, Zarządzanie od podstaw, Wolters Kluwer, Warszawa.

[15] KRóL H., LudwiCzyŃski A., 2006, Zarządzanie zasobami ludzkimi, PWN, Warszawa.

[16] Listwan T. (red.), 2005, Słownik zarządzania kadrami, C.H. Beck, Warszawa.

[17] Nowicka J., 2014, Miejsce i rola kultury organizacyjnej w motywowaniu pracowników, [w:] Zeszyty Naukowe Uniwersytetu Przyrodniczo-Naukowego w Siedlcach, nr 102, Seria Administracja i Zarządzanie (29) 2014, Siedlce.

[18] Pocztowski A., 2007, Zarządzanie zasobami ludzkimi: strategie - procesy - metody, Polskie Wydawnictwo Ekonomiczne, Warszawa.

[19] Roos J., Roos G., Dragonetti N. C., 1997, Intelelectual Capital-Navigating in the New Business Landscape, Macmillan Press.

\section{NETOGRAFIA}

[20] BALEwski B., Zarzadzanie kadrami, http://www.balewski.pl/media_f_450/file/702_pl_wyklad_zarzadzanie_kadrami_1_i_2.pdf (25.09.2016). 